\title{
Nominalization and Argument Structure in Early New High German"
}

\author{
Ulrike Demske \\ Tübingen/Jena \\ ulrike.demske@uni-tuebingen.de
}

\begin{abstract}
Recent work on argument selection couched in a lexical decomposition approach (Ehrich \& Rapp 2000) postulates different linking properties for verbs and nouns, challenging current views on argument inheritance. In this paper, I show that the different behavior with respect to verbal and nominal linking observed for Present-Day German does not carry over to ungnominals in Early New High German. Deverbal nouns and corresponding verbs rather behave alike with respect to argument linking. I shall argue that this change is motivated by the growing rift between ung-nominals and their verbal bases both focussing on different parts of their lexicosemantic structure in Present-Day German. Evidence for the verb-like behavior of ung-nominals in Early New High German comes from the regular meaning relation between verbs and corresponding derived nouns, the actional properties of event-denoting nouns, and the patterning of ung-nominals with nominalized infinitives. Even their syntactic behavior reflects the verbal character of ung-nominals during that period of the German language. The diachronic facts can be accounted for in a straightforward way once we adopt a lexical decomposition approach to argument selection.
\end{abstract}

\section{$1 \quad$ Introduction}

In this paper, I shall be concerned with the relationship between $u n g$-nominals and their verbal counterparts in Early New High German (ENHG). In particular, I shall be looking at the linking properties of deverbal nouns and their verbal bases.

Data like (1) suggest a systematic relationship between the argument structures of verbs and nouns, respectively:

(1) a. Paul züchtet solche Schnecken.

'Paul is breeding such snails'

b. Pauls Züchtung solcher Schnecken

'Paul's breeding of such snails'

Morpho-syntactic accounts describe the relationship between the verb in (1a) and the argument taking noun in (1b) in terms of argument inheritance: the derived noun inherits the internal argument of its verbal base with verbs and nouns displaying different case assignment porperties, i.e. accusative and genitive case, respectively. Thematic roles of arguments are supposed to play no role with respect to argument inheritance.

In a recent paper, Ehrich \& Rapp (2000) challenge current views on argument inheritance, stressing that morpho-syntactic accounts fail to provide an explanation for the contrast displayed in (2) and (3):

(2) a. Die Verfolgung des Verbrechers war nicht erfolgreich.

'the trailing of the criminal was not successful'

\footnotetext{
* This article has benefited from comments of the audience at the Tïbingen workshop on nominalization, in particular Hagit Borer, Veronika Ehrich, Jane Grimshaw, Klaus von Heusinger, Irene Rapp, Marga Reis, Barbara Stiebels, and Ilse Zimmermann.
} 
b. Keiner entgeht der Verfolgung der Polizei. 'nobody escapes the trailing by the police'

(3) a. Die Vollendung eines menschlichen Klons steht kurz bevor. 'the completion of a human clone is fast approching'

b. Die Vollendung des Wissenschaftlers steht kurz bevor. 'the completion of the scientist is fast approaching'

Though both verfolgen 'trail' as well as vollenden 'complete' are transitive verbs, only verfolgen allows its external argument to surface as a genitive complement of the deverbal nominal (cf. (2b)). Interpreting the genitive complement of Vollendung 'completion' as the external argument, however, is excluded, cf. (3b). To account for the data given in (2) and (3), Ehrich \& Rapp suggest an explanation in terms of a lexical decomposition approach, assuming different linking properties for verbs and deverbal nouns.

Although Ehrich \& Rapp's account of nominal linking seems to capture the data in Present-Day German (PDG) in a straightforward way, I am going to show that it fails to make the right predictions for ung-nominals in ENHG. I consider this to be a result from language change: In earlier periods of German ung-nominals are recategorizations of verbs only in a syntactic sense, sharing with their verbal stems linking properties and sortal interpretation. Regarding the latter properties, deverbal nouns evolve a more noun-like character not until a fairly recent stage in the history of German.

The outline of this article is the following: In section 2, I briefly sketch the account for verbal and nominal linking as proposed by Ehrich \& Rapp (2000). I present the ENHG data in section 3, paying particular attention to the argument structure of ung-nominals. Section 4 deals with other respects of their linguistic behaviour in ENHG, providing further evidence for the verbal character of ung-nominals. Section 5 is an attempt to ascribe the changes determining the history of $u n g$-nominals since the $17^{\text {th }}$ century to a nominalization process with 'nominalization' taken literally. Section 6 gives a conclusion.

The following discussion is based on data mainly collected in newspapers of the $16^{\text {th }}$ and $17^{\text {th }}$ century. Newspapers provide a data base that is appropriate in two respects: first, they show stylistic variation, since they include a number of different registers, such as documents, letters, and so on. Second, newspapers exhibit dialectal variation, since each issue of the newspaper includes contributions from a number of scribes from different dialect areas. The data base is also huge enough to ensure the reliability of the proposed analysis ( 381 types, 2109 tokens of $u n g$ - nominalizations).

\section{Verbal and nominal linking in Present-Day German}

\subsection{Verbal linking}

Following current views on the structure of the lexicon (Bierwisch 1983, 1996; Jackendoff 1990, Wunderlich 1997), Ehrich \& Rapp (2000) assume that the lexical meaning of verbs can be decomposed into basic predicates indicating thematic structure as well as event structure of verbs. Argument structure is derived from this lexicosemantic structure by means of $\lambda$ abstraction. Ehrich \& Rapp argue that it is only thematic structure that determines verbal linking,' illustrated in (4) for semantic verb classes denoting different sorts of entities, namely activities, states, and events. The referential arguments are represented by variables such as $r$, $s$ and $e$ :

\footnotetext{
' In this respect they crucially differ from accounts deriving linking properties from event structure, cf. Grimshaw (1990) among others.
} 
(4) a. Sie verfolgt den Einbrecher.

'she trails the burglar'

$\lambda y \lambda x \lambda r[D O((x, y) r)]$

$$
x=\theta 1, y=\theta 2
$$

b. Er bewundert die Altistin.

'he admires the alto'

$\lambda y \lambda x \lambda s[\operatorname{POSS}((x, y) s)]$

$$
x=\theta 1, y=\theta 2
$$

c. Sie erreichten den Gipfel.

'they reached the top of the hill'

$\lambda y \lambda x \lambda$ e [BEC $((\operatorname{APPL}((x, y) s)) e)]$

$$
x=\theta 1, y=\theta 2
$$

d. Sie vollendeten den menschlichen Klon.

'they completed the human clone'

$$
\lambda y \lambda x \lambda e[D O((x, y) r) \& B E C((B E((y) s)) e)] \quad x=\theta 1, y=\theta 2
$$

The lexicosemantic structure of the activity verb in (4a) as well as the state verb in (4b) consist of only one basic predicate, namely DO and POSS(ESS). The individual arguments of both predicates ( $\mathrm{x}$ and $\mathrm{y}$ ) are linked to the positions of subject and direct object, respectively. With respect to events, we have to distinguish at least between two types of events: ${ }^{2}$ accomplishments denote events having both a development portion and a culmination point. In contrast, achievements refer to events lacking this development portion, they are instantaneous events. The lexical semantic structure of achievements is said to be complex, because the predicate $\mathrm{BEC}(\mathrm{OME})$ selects another predicate (and not individual arguments). The predicate selected by BEC is APPL(ICATION), with APPL expressing a local relation between its thematic arguments $x$ and $y, c f .(4 c)$. The accomplishment in (4d) comprises three basic predicates: besides the $\mathrm{BEC}$ predicate selecting for $\mathrm{BE}$ with a single thematic argument, we find the BEC predicate related to a DO predicate by means of conjunction: ${ }^{3}$ the first conjunct refers to the activity bringing about the change of state expressed by the second conjunct. With respect to argument selection the achievements and accomplishments given in (4) behave as activities and states: both thematic arguments are linked to subject and object position, respectively.

Linking conflicts arise as soon as the BECOME predicate embeds a two-place predicate, as illustrated in (5) for causative accomplishments such as leihen 'lend' and besprühen 'spray':

a. Er lieh ihm sein Fahrrad.

'he lent him his bike'

$\lambda y \lambda z \lambda x \lambda e[\operatorname{DO}((x, y) r) \& \operatorname{BEC}((\operatorname{POSS}((z, y) s)) e)] \quad x=\theta 1, y=\theta 2, z=\theta 3$

b. Sie besprühte die Wand mit roter Farbe.

'she sprayed the wall with red paint'

$\lambda y \lambda x \lambda e[D O((x, y) r) \& \operatorname{BEC}((\operatorname{APPL}((z, y) s)) e)] \quad x=\theta 1, y=\theta 2$

In (5a) the first arguments of both the DO and the POSS predicate compete with respect to the subject position: since the first argument of the DO predicate obviously wins the linking conflict, the experiencer argument is realized as a dative object. In (5b), competition arises between the first arguments of the DO and the APPL predicate with respect to the subject position: in contrast to (5a) the first argument of the embedded predicate cannot be realized as a

\footnotetext{
${ }^{2}$ Rapp (2001a:197) assumes a four-way distinction: (i) non-causative achievements (einschlafen 'fall asleep'), (ii) causative achievements (erschlagen 'strike dead'), (iii) non-causative accomplishments (verblühen 'fade'), and (iv) causative accomplishments (verbiegen 'buckle).

${ }^{3}$ Conjuncts in a lexicosemantic structure are assumed to be causally related; cf. Wunderlich (1997) for the following redundancy rule: P1 ((..) v1) \& P2 ((..) v2) つ CAUSE ((v1, v2) v2).
} 
dative object, because the position labelled $\theta 3$ is generally assumed to be confined to arguments with typical experiencer properties. Hence, the first argument of the APPL predicate either remains implicit or is realized as a prepositional phrase (as an argument adjunct in the sense of Grimshaw 1990). Ehrich \& Rapp emphasize the fact that with respect to linking conflicts the arguments of the DO predicate always win over the arguments embedded under the predicate of the second conjunct.

\section{$2.2 \quad$ Nominal linking}

On the assumption that nouns have an argument structure as verbs do, Ehrich \& Rapp observe the following differences regarding argument selection with nominals:

(i) Nominal arguments are optional.

(ii) Thematic and event structure of nouns determine the nominal argument structure as the thematic and event structures of verbs do.

(iii) With respect to event-denoting nominals, nominal linking favors the state part of the lexicosemantic structure over the DO part.

In particular, Ehrich \& Rapp state the following two rules governing argument linking with deverbal nouns:

\section{Argument Structure of ung-nominalizations}

(a) If and only if the lexical semantic structure contains no change of state part, all thematic arguments appear in the argument structure, otherwise

(b) the nominal argument structure is restricted to the lowest affected argument of the lexical semantic structure.

\section{Nominal linking}

(a) Each thematic argument of the argument structure may be realized as a postnominal $\mathrm{NP}_{\mathrm{GEN}}$.

(b) No thematic argument has to be realized.

To see how the particular clauses work, consider the examples under (8). The bracketing of $\lambda$ operators indicates the optionality of thematic arguments.
(8)
a. Verfolgung
'trailing'
b. Bewunderung 'admiring'
$(\lambda y)(\lambda x) \lambda r[D O((x, y) r)]$
$(\lambda y)(\lambda x) \lambda s[\operatorname{POSS}((x, y) s)]$

With process and state nominals all arguments of the lexicosemantic structure are also part of the noun's argument structure, as indicated by clause (6a). Apart from the optionality of arguments the nominal argument structure parallels the argument structure of the corresponding verbs. With event nominals, however, systematic differences characterize the linking properties of verbs and nouns: according to clause (6b) only arguments embedded under BEC may appear in the noun's argument structure, while arguments of the DO predicate remain implicit. In case the predicate BEC embeds a two-place predicate (cf. (9b)), only the lowest argument becomes part of the noun's argument structure.
(9)
a. Vollendung
'completing'
b. Erreichung
'reaching'

$$
\begin{aligned}
& (\lambda y) \lambda e[D O((x, y) r) \& \text { BEC }((B E((y) s)) e)] \\
& (\lambda y) \lambda e[B E C((\operatorname{APPL}((x, y) s)) e)]
\end{aligned}
$$


Deriving nominal argument structures as proposed by Ehrich \& Rapp (2000), makes the right predictions for the interpretation of the noun's complements under (10): only process and state nominals as in (10a) and (10b) are ambiguous between a subject and an object reading.

(10) a. die Verfolgung des Mannes

'the trailing of the man'

b. die Bewunderung des Filmemachers

'the admiration of the film-maker'

Mann 'man' as well as Filmemacher 'film-maker' can be interpreted as both the subjet or the object argument of the DO and the POSS predicate in the nominal lexicosemantic structure. With events, however, the interpretation of genitive complements is unambiguous. Event nominals only allow for the lowest affected argument of the lexicosemantic structure to appear in the argument structure.

(11) a. die Erreichung des Gipfels

'the reaching of the summit'

b. *die Erreichung der Bergsteiger

'the reaching of the climbers'

(12) a. die Vollendung eines menschlichen Klons

'the completion of a human clone'

b. *die Vollendung des Wissenschaftlers

'the completion of the scientist'

Hence, the only reading available for a post-nominal genitive complement seems to be the object reading. Whereas (11b) is ruled out for semantic reasons, we might understand (12b) as the completion of a cloned scientist, not however, as the scientist's completion of some project. In contrast, genitive complements of event nominals based on one-place predicates always get a subject reading.

$$
\begin{aligned}
& \text { die Erstarrung der Lava } \\
& \text { 'the fossilizing of the lava' } \\
& (\lambda \mathrm{x}) \lambda \mathrm{e}[\mathrm{BEC}((\mathrm{BE}((\mathrm{x}) \mathrm{s})) \mathrm{e})]
\end{aligned}
$$

Though ung-nominals share the event structure with their verbal counterparts in many cases, as the examples given above for process, state and event nominals illustrate, nominals based on accomplishments offer a whole range of sortal interpretations: ung-nominals derived from accomplishments exhibit state or object readings besides an event interpretation. The examples below (taken from Ehrich \& Rapp 2000:267) show the array of interpretations related to only one ung-nominal:

(14) a. Nach der Bemalung der Wand mit Farbe sind die Kinder weggelaufen. after the painting of the wall with paint have the children run off 'after painting the wall, the children ran off'

$(\lambda y) \lambda \mathrm{e}[\mathrm{DO}((\mathrm{x}, \mathrm{y}) \mathrm{r}) \& \operatorname{BEC}((\operatorname{APPL}((\mathrm{z}, \mathrm{y}) \mathrm{s})) \mathrm{e})]$

b. Die Bemalung der Wand besteht unverändert fort. the painting of the wall continues unchanged 'the painted wall continues unchanged' $(\lambda y) \lambda s[D O((x, y) r) \& \operatorname{BEC}((\operatorname{APPL}((z, y) s)) e)]$

c. Der Hausmeister hat die Bemalung der Wand entfernt. the janitor has the painting of the wall removed 
'the janitor has removed the painting at the wall'

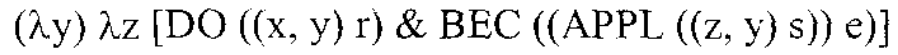

According to the individual predicates in their lexicosemantic structure, event nominals as Bemalung 'painting' can refer to (i) events, focussing on both conjuncts of the complex predicate, (ii) states, focussing on the target state, and (iii) concrete and abstract objects resulting from the activity in question. Given the appropriate context, an ung-nominal derived from an accomplishment may even be interpreted as denoting a process, stressing only the DO predicate in its lexical semantic structure, $c f$. (15a), with the process reading also licensing the realization of the DOer argument, $c f .(15 b)$ :

(15) a. Erist bei der Bemalung der Wand vom Stuhl gefallen. he has while the painting of the wall the chair down fallen 'while painting the wall, he has fallen down a chair' $(\lambda y)(\lambda x) \lambda r[D O((x, y) r)]$

b. Die Bemalung des Künstlers hat großes Aufsehen erregt. the painting of the artist has great sensation caused 'the artist's painting has caused a great sensation'

According to Ehrich \& Rapp, the process reading of accomplishment-based nominals is restricted to nominals derived from particular verb classes denoting modifications of entities such as bemalen 'paint' (cf. (14)), as well as verbs such as kürzen 'shorten' and umgestalten 'alter'. ${ }^{4}$

Considering the linking properties of nouns and verbs, a crucial difference arises with respect to event nominals: whereas verbal linking conflicts suggest that verbs favor the DO part over the change of state part of the predicate, thus highlighting the dynamic aspect of the verbal category, the argument structure of event nominals indicates that deverbal nouns rather focus the change of state part in their lexical semantic structure. As I am going to show in the following section, these differences with respect to argument linking are not met by the ENHG data.

\section{$3 \quad$ Linking properties of $u n g$-nominals in Early New High German}

Ung-nominalization seems to be a very productive word formation pattern in ENHG, as suggested by the large number of tokens found in texts from the $17^{\text {th }}$ and $18^{\text {th }}$ century. By far the most attested examples are $u n g$-nouns denoting eventualities, whereas object readings do not occur very frequently. ${ }^{5}$ Some examples are listed in

(16)

Behausung
Besoldung
Festung
Kleidung
Nahrung
Ordnung
Wohnung

'housing'
'paying'
'fortress'
'clothing'
'nourishment'
'order'
'apartment'

In the remainder of this paper, my focus will be on the overwhelming number of ungnominals denoting eventualities, i.e. ung-nominals with an internal temporal structure.

\footnotetext{
${ }^{4}$ Ehrich \& Rapp (2000:290) refer to these verbs as 'Bearbeitungs-' und 'Modifikationsverben', respectively.

${ }^{5}$ Though object readings are restricted to a small number of ung-nominals regarding types, the few attested nominalizations are used quite frequently, thus providing for a larger number of tokens.
} 
Ung-nominalizations based on atelic verbs as activities and states yield process and state nominals with genitive phrases co-occuring with process nominals either interpreted as the underlying subject or the underlying object.

(17) a. Von Constantinop. hat man/ demnach der Rebell. Joseph Bassa [...] from C. have we, after the rebel Joseph Bassa

des Veziers Musterung vernommen/ hat er sich mit 12000. Mann

the vizier's inspection heard/ has he himself with 12000 men

an ein sichern Ort begeben/

to a safe place betaken

$($ A 209.14)

'as far as we know from Constantinople, the rebel J. B. has betaken to a safe place with 12.000 men after hearing from the vizier's inspection'

b. was vnd so viel die Musterung der gemeinen Landts Vnterthanen betrifft what and how much the inspection of the common subjects concerns

'concerning the common subjects' inspection'

In (17a), the underlying subject Veziers 'vizier's' appears as an argument of the process nominal; in (17b) it is the underlying object that figures as the deverbal noun's argument. In contrast to PDG, the pre-nominal occurrence of genitive complements is not restricted to proper names, kinship terms and some pronouns. All arguments of a deverbal noun are free to either precede or follow the head noun, as shown for the object of the process nominal beratschlagung 'discussing'.
a. Zu Preßburg wil man zu beratschlagung der Proposition nicht schreiten/ in Preßburg will one with discussing of the motion not proceed

es werde dann zuuor ein Palatinus erwehlt/

there will then before a Palatinus elected

'one will not proceed with discussing the motion in Preßburg'

b. weil die aus den Ständen [...]/ ohne resolvierung vnnd erörterung because these from the estates without resolution and discussion

$\begin{array}{lll}\text { gedachter Puncten } & \text { zu der Proposition Berahtschlagung } & \begin{array}{l}\text { zugreiffen } \\ \text { of the above mentioned points }\end{array} \\ \text { to the motion's discussing } & \text { advance }\end{array}$

(A 273.16)

'because members of the estates [...] advance to discuss the motion'

Further instances of argument linking along these lines are attested with the following process nominals:

(19) begleitung

belägerung

bemühung

'accompagnying'

'besieging'

continuierung

'endeavouring'

erhebung

'continuation'

streiffung

'raising'

'roaming'

\footnotetext{
"Given is the short name of the source text, including the page number and the line indicating the beginning of the historical example.
} 
$\begin{array}{ll}\text { versamblung } & \text { 'assembling' } \\ \text { versterckung } & \text { 'reinforcing'. }\end{array}$

Ung-nouns based on state verbs pattern with process nominals regarding argument selection: genitive complements express either the external or the internal argument of the verbal base.

(20) a. Es continuirt Frater F. / mit grossem Eifer vnd menniglichs verwunderung it continues Frater F. with great enthusiasm and a good many's astonishing

die Evangel. Lehr/ [...]/ in die Hertzen der Zuhörer zu imprimirn/ (A.103.17) the Protestant teachings in the hearts of the audience to stamp

'Frater Fulgentius continues to stamp the Protestant teachings in the hearts of his audience with great enthusiasm and a good many's astonishment'

b. welcher jne dargegen/ in erwegung außgestandner gefahr/ mit 600. Cr. begabet who him therefore, in considering endured danger, with $600 \mathrm{cr}$. endowed

(AC 197.11)

'considering however endured danger, he endowed him with 600 Crowns'

The subject argument of the state verb is realized pre-nominally ((20a)), whereas the object argument follows the deverbal noun in (20b). Further instances of state nominals exhibiting similar linking properties are given below:

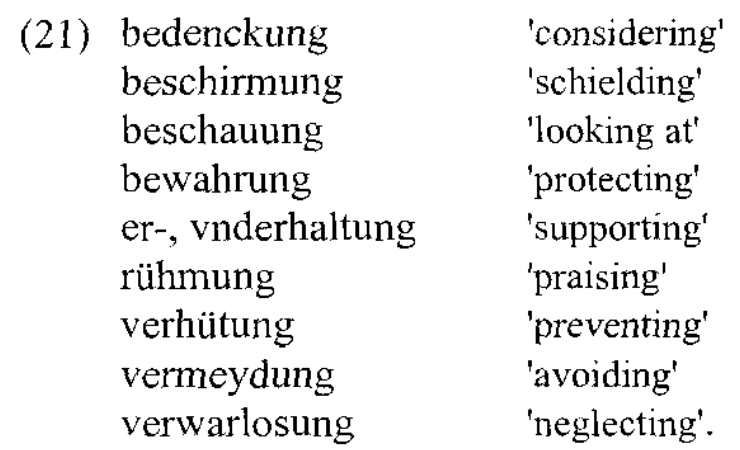

So far, we observe no differences between argument linking in PDG and ENHG with respect to deverbal nouns: process nominals as well as state nominals pattern with their PDG counterparts. Recall, however, that ung-nominals denoting processes and states share the argument structure with their verbal stems.

Ung-nominalizations based on telic verbs display a quite different picture. In PDG, the linking properties of the respective ung-nominals exhibit systematic differences as compared to the linking properties of their verbal bases. Since event nominals focus the state of change predicate in their lexical semantic structure, only the lowest affected argument is mapped to argument stucture, i.e. the genitive complement of an event nominal will always get an object reading with the exception of one-place event nouns such as Verdunstung 'evaporation' or Erstarrung 'fossilization' where the genitive is restricted to a subject reading. How do the event nominals of the $17^{\text {th }}$ and $18^{\text {th }}$ century fit in this picture? I begin by looking at event nouns derived from accomplishments. In contrast to PDG, event nominals combine as easily with the object-denoting as with the subject-denoting participant, as illustrated for Abfertigung 'dealing with' in (22) as well as Berufung 'summoning' in (23):

(22) a. Man tractirt starck
they negotiate intensively

'the dealing with the Turkish ambassador is intensively dealt with' 
b. Brieff auß Pariß melden/ das die 2. Graffen von Solms/ wie der Graff von letters from Paris report that the 2 Counts of S. and the Count of

Hohenzollern/ noch daselbsten auff des Königs abfertigung warten. (A 308.31) Hohenzollern still there for the King's dealing with wait

'As reported through letters from Paris, that both Counts of Solms as well as the Count of Hohenzollern are still waiting there for the King to deal with them'

(23) a. Es sollen die geheime Räht/ die allher beruffung des Ertzhertzogs Leopoldi it should the privy councils the hither summoning of the Archduke Leopoldi

vnnd Beyerfürsten/ [...] sehr befrembden

and Bavarian Prince $[\ldots]$ very much displease

'the privy councils are said to be rather displeased by summoning the Archduke and Bavarian Prince Leopoldi here'

b. er wird aber heut oder morgen vff beruffung Jhrer Mayst. wieder he is however today or tomorrow upon summoning of His Majesty again

zu rück von Gretz allhero verwart back from Gretz here expected

'he, however, is expected to be back from Gretz today or tomorrow upon summoning by His Majesty'

Whereas the (a)-examples in (22) and (23) represent deverbal head nouns with the genitive complement expressing the underlying object, the genitive complement in (22b) and (23b) have to be interpreted as underlying subjects. Both arguments, the underlying subject as well as the underlying object may either precede or follow the deverbal head noun, as shown by the above examples. The linking properties of event nouns thus suggest that the argument structure of ung-nominalizations is build up by the same arguments as the argument structure of the verbal bases with the agent argument included in the noun's argument structure, cf. also example (24), to emphasize this particular property of event nominals in ENHG:

$\begin{array}{lllll}\text { Als } & \text { Graff Moritz von Nassaw / [...] } & \text { zum Haag wider } & \text { ankommen / hat er } \\ \text { when Count Moritz v. N. [...] } & \text { at Haag again arrived has he }\end{array}$

mit schmertzen befunden / das sein Schwester/mit des Don Antonij di Portugall regretfully discovered that his sister to Don Antonij di Portugal's

Schmeisch / auß anstifftung etlicher Geistlicher Ehelich verlobt / (AC 180.23) Schmeisch upon putting up of some clergymen maritally engaged (was)

'when Count Moritz of Nassau arrived at Haag again, he discovered to his great sorrow that his sister was married to Don Antonij di Portugal's Schmeisch upon putting up by some clergymen'

In PDG, the agent only co-occurs with accomplishment-based nominals exhibiting a process reading. As far as I understand the data in (22b), (23ab) and (24), such a reading is not available for the ung-nominals in question. The appearance of the agent argument rather suggests that accomplishment-based nominals have an additional argument in their argument structure in ENHG as compared to their counterparts in PDG.

fertigung 'making'

$(\lambda y)(\lambda x) \lambda e[D O((x, y) r) \& \operatorname{BEC}((B E((y) s)) e)]$ 
Co-occuring with either the subject and/or object complement are also event nominals such as the following:

$\begin{array}{lll}\text { verbs of creation: } & \text { erbawung } & \text { 'building' } \\ & \text { fertigung } & \text { 'making' } \\ & \text { vollendung } & \text { 'completion' } \\ \text { verbs of transformation: } & \text { außbawung } & \text { 'extending' } \\ & \text { befestigung } & \text { 'fortifying' } \\ \text { verbs of destruction: } & \text { erseuffung } & \text { 'drowning' } \\ & \text { niederreissung } & \text { 'pulling down'. }\end{array}$

However, there are two cases to consider where the agent argument lacks with event nominals based on accomplishments. Regarding first event nominals with a two-place predicate embedded under BEC, the linking rules suggested by Ehrich \& Rapp for PDG predict that only the theme argument should figure in the noun's argument structure. ${ }^{7}$ Probably due to the limits of a restricted data base, this prediction is also borne out for the ENHG data:

(27) a. Dem Visconte de Tauanes. welcher mit dem Gran Prior. Gubernatore in Auuergnia the Visconte de Tauanes. who with the Gran Prior Governor of Auvergne

[...] / in vbergebung etlicher Stätt in Auuergnia. in gleicher Conspiration gewesen/ in handing over of some towns in Auvergne in same conspiration been (has)

[...] / hat der König von Franckreich/ das Haupt abschlagen lassen. (AC 119.24) has the King of France the head cut off had

'the Visconte de Tauanes. who has been in conspiration with the Gran Prior. Governor of Auvergne in handing over some towns in Auvergne'

b. Die 50000. Thaler zu der Türckischen Present weiln solche nicht auffzubringen/ the 5000. Thaler to the Turkish present because those not to raise (were)

hat sich der Jllishaskij gegen einraumung der Herrschafft Vngarisch Altenburg has the Jllishaskij against conceding of the domain Hungarian Altenburg

herzugeben erbotten/ welche jhme bereit solle zugesagt sein. (R 27.22) to contribute volunteered that him already should promised be

'J. has volunteered to contribute the missing 5000 Thaler to the Turkish present [...]upon conceding him the domain of Hungarian Altenburg'

Consider nominals denoting target states next. Their argument structure is derived from the lexicosemantic structure of accomplishments according the rules suggested by Ehrich \& Rapp for PDG. With event nominals they share the property that only the lowest affected argument becomes part of the noun's argument structure. Target state nominals differ from event nominals with respect to their sortal interpretation. The historical data suggest that they have the

\footnotetext{
${ }^{7}$ According to Eisenberg (1998:267), verbs taking a dative object are excluded as potential bases for ungnominalizations for structural reasons (*Helfung 'helping', *Dankung 'thanking', *Gefallung 'pleasing', ...). He ascribes this restriction to the fact that nominals do not select for dative phrases. As shown by the ENHG data, however, we find verbs as einreumen 'concede', vberantworten 'place sth in sb's hands', vbergeben 'present', vberreichen 'hand over', and vbertragen 'assign' figuring as bases for ung-nominals. All ung-nominals based on dative verbs only select for a theme argument as far as the data base tells. Neither the DOer argument nor the experiencer argument of these three-place verbs are attested - as expected on Ehrich \& Rapp's approach. But ung-nominals derived from two-place dative verbs are not an issue in Ehrich \& Rapp's (2000) proposal.
} 
same argument structure as they do in PDG, namely lacking the agent, as shown for the ENHG nominal versperrung 'locking':

(28) a. wie dann beyde Herrn von Collonitsch/vnd Bucheimb/ sich noch Gestern as then both lords of Collonitsch and Bucheimb REFL already yesterday

auß der Stadt begeben/ vnd jhres Gegentheils vor der Stadt gewart/ out of town betook and for their party outside of the town waited

welche aber wegen der versperrung der Thor/ nicht erscheinen können. who however because of the locking of the gates not appear could

(A 293.12)

'both the lord of Collonitsch and the lord of Bucheimb then betook out of town yesterday, waiting for their negotiating party outside the town gate, who, however, couldn't appear because of the locked gates'

b. versperrung 'locking'

$(\lambda y) \lambda s[D O((x, y) r) \&$ BEC $((\operatorname{APPL}((z, y) s)) e)]$

Let us now turn to event nominals derived from achievements, i.e. verbs denoting a single change of state. Only a few instances are attested (cf. empfangung 'receiving', verlierung 'losing'). The deverbal noun combines with the theme argument in almost all examples, illustrated with verlierung 'losing'.

$$
\begin{aligned}
& \text { und straffet die tochter seer bey verlierung seiner huld, } \\
& \text { and (he) punishes the daughter hard with losing of his grace } \\
& \text { wo sy des edelmanns nit mu:essig gange } \\
& \text { if she the nobleman not alone leave }
\end{aligned}
$$

'in case she wouldn't leave the nobleman alone he is going to punish his daughter hard by withdrawing his grace'

One single example in the corpus might be interpreted as showing at the same time the subject and the object of the single change of state verb verlieren 'lose' with both arguments appearing in a post-nominal position

$$
\begin{array}{llll}
\text { Diese tag haben J. Keys. M. } & \text { ernstliche } & \text { vnd scharffe Mandata } & \text { außgehen } \\
\text { these days have His Imp. Majesty } & \text { serious } & \text { and tough decrees } & \text { sent out }
\end{array}
$$

vnd publicirn lassen/daß bey verlierung der protestirenden Stendt/Haab vnd and published had that with losing the protesting estates' possessions'

Güter/ jhre Zusamenkunfft auff der Newstadt wieder einstellen sollen/ their meeting in the new town again discontinue should

(A 115.31)

'these days His Imperial Majesty have had serious and tough decrees sent out and published, namely that the protesting estates should discontinue their meeting in the new town, losing their possessions otherwise',

where die protestirenden Stendt 'the protesting estates' refer to the subject and Haab und Gut 'possessions' to the object of verlierung 'losing'. Note that in PDG a genitive complement must appear adjacent to the head noun, either preceding or following it. ${ }^{8}$

\footnotetext{
${ }^{8}$ The postnominal position of both genitive complements probably suggests another reading of (30) where the protesting estates are the possesssor argument of possessions, cf. the preceding example (29) with a possessive pronoun. But cf. also (31c) indicating that adjacency of genitive complements is not obligatory in ENHG.
} 
One-place achievement predicates clearly outnumber the two-place achievements as verbal bases of ung-nominals in ENHG. Regarding their linking properties, the deverbal nouns behave as expected: the genitive complement always gets a subject reading.

(31) a. Wegen abbleibung deß Bischoffs zu Bisilo in Calabria vacirt, due to deceasing of the bishop of Bisilo in Calabria is vacant

derselben Kirchen einkommen von 1500 . Cronen.

this church's income of 1500 crowns

'due to the decease of the bishop of Bisilo in Calabria, the curch's salary [...] is vacant'

b. Aus Ambsterdam hat man/ daß daselbst vnd ander Orten in Niderland from Amsterdam gets one that at that place and at other places in the Netherlands

ein sehr grosse Springflot vnd erhebung des Meers gewesen sey/ a very big spring tide and rising of the sea been has

'as one gets from Amsterdam, there has been a verry big spring tide and rising of the sea'

c. welche nach vmbkommung beyderseits viel Volcks in die Flucht gebracht/ who after perishing on both sides lots of people to flight put

'who have been put to flight after lots of people were killed on both sides'

As indicated by (31c), a local adjunct may intervene between a head noun and its genitive complement, hence no adjacency requirement seems to govern the position of nominal complements in ENHG.

More instances of one-place event nominals include the following nominalizations:

$\begin{array}{ll}\text { besserung } & \text { 'recovering' } \\ \text { endigung } & \text { 'ending' } \\ \text { umstürzung } & \text { 'overturning' }\end{array}$

I last consider a class of verbs including psychological causatives as beleidigen 'offend', begeistern 'inspire', enttäuschen 'disappoint' etc. Following Rapp (2001b), I assume that psychological causatives pattern with verbs such as gefährden 'endanger' and behindern 'obstruct' regarding their linking properties. In the literature they are sometimes called stimulus-subject verbs (Wechsler 1995). As with complex changes of state, the lexicosemantic structure of stimulus-subject verbs consists of two conjuncts, illustrated for gefährden in

$$
\text { gefährden 'endanger' }
$$

$$
\lambda y \lambda x \lambda s[\mathrm{P}(\ldots \mathrm{x} \ldots), \mathrm{BE}((\mathrm{y}) \mathrm{s})] \text {. }
$$

Stimulus-subject verbs denote a state as indicated by the referential argument $s$ in their argument structure, with the first conjunct $P$ remaining unspecified with respect to its sortal classification. The argument structure of derived nouns is restricted to the theme argument of the embedded BE predicate as in"

(34) a. die Gefährdung der Skifahrer/*der Lawinen

the endangering of the skiers/of the avalanches

\footnotetext{
${ }^{9}$ Rapp $(20016: 20)$ suggests to extend the notion of affected argument to capture the linking properties of stimulus-subject verbs. Her version of Ehrich \& Rapp's (2000) nominal linking rule is as follows:

All arguments are affected that

(i) are embedded under BECOME and/or

(ii) appear in the second conjunct of a causative lexical semantic structure.
} 


\section{b. die Behinderung des Verkehrs/*der Schafe \\ the obstructing of the traffic/of the sheep,}

while realizing the stimulus argument yields ungrammatical results (cf. Rapp 2001b). The lexicosemantic structure of an ung-nominal hence has the following representation:

$$
\text { Gefährdung 'endangering' }
$$

$$
(\lambda y) \lambda s[P(\ldots x \ldots), B E((y) s)] \text {. }
$$

In contrast to PDG, the stimulus argument appears as genitive complement of deverbal nouns in ENHG.

Der Sigmundt Bathori/ Fürst in Siebenbürgen/ welcher ein zeitlang zu Lipochowitz the Sigmundt Bathori prince in Transylvania who for some time at Lipochowitz

gewohnt/ vnd wegen seiner hergeliehenen grossen Geldtsumma auff die lived and because of his giving a huge amount of money to the

Herrschafft Cromaw verwiesen/ [...]/ jhme aber wegen böser finantzischer Räht domain Cromau bestowed [...] him however due to malevolent financial officials'

verhinderung nicht Glauben gehalten worden/ ist vor wenig Wochen gar obstructing not word kept been has a few weeks ago completely

vnuermerckter Sachen/ [...]/ heimlich aus diesem Königreich geschieden/ (A 193.15) unnoticed $[\ldots] \quad$ secretly this kingdom departed

'Sigmundt Bathori, prince in Transylvania, who lived for some time at Lipochowitz, bestowed to the domain Cromau because of the huge amount of money he has given, has secretly departed this kingdom, because word has not been kept to him due to an obstruction caused by malevolent financial officials'

The historical facts suggest that no systematic differences hold between nominal and verbal linking with respect to argument selection in ENHG. Regarding their linking properties, ungnominals and their verbal counterparts rather behave alike. This is shown in particular by the linking properties of event-denoting nominals and nominals derived from stimulus-subject verbs with the agent and the stimulus argument being mapped to the nominal argument structure only in ENHG, while deverbal nouns in PDG do not select these arguments. The conclusion to be drawn from the historical data is that ung-nominalizations are recategorizations without any systematic effect on the derived nominal's lexicosemantic structure. Recall that verbs are supposed to stress the dynamic part, while deverbal nouns rather focus on the change of state or state part (including the stimulus-subject verbs) of a predicate in PDG.

\section{The word formation pattern in Early New High German}

In this section, I shall provide further evidence for the verb-like behavior of ung-nominals and hence the close relationship between deverbal nouns and their verbal bases in ENHG.

\subsection{The relation between verbs and deverbal nouns}

The relation between deverbal nominals and their verbal counterparts seems to be rather productive in ENHG. Ung-nominalizations show no restrictions with respect to potential verbal bases, in particular, no semantic restrictions are attested, as illustrated below with verkaufen 
'sell', a verb referring to a change of possession. Note that verbs of this semantic class are excluded as bases of ung-nominalization in PDG (cf. (37b)). ${ }^{10}$

(37) a. Die Buch-Verkauffer in Pariß sollen wegen Verkauffung unangenehmer Bücher the book-sellers in Paris should because of selling unpleasant books

auff 20 . à 25 . reduciret werden.

(M 123.1)

to 20 or 25 reduced be

'on account of selling unpleasant books, the book-sellers in Paris are supposed to be reduced to 20 or $25^{\prime}$

b. Der Verkauf/*die Verkaufung von Tickets an der Abendkasse läuft gut the sale/ *the selling of tickets at the box office is going well

It is commonly assumed (cf. Esau 1973, Wellmann 1975, Ehrich 1977, Bartsch 1985, Oh 1985, Ehrich 1991) that verbs expressing states as well as verbs referring to the beginning or the repetition of a situation do not function as bases for ung-nominals either, as shown in (38a) through (38c).
a. *Glaubung
* Sehung
b. *Aufleuchtung
*Loslachung
c. *Hüstelung
*Streichelung
'believing'
'seeing'
'lighting up'
'bursting out laughing'
'giving a slight cough'
'stroking'

As for verbs referring to a change of possession, instances of these verb classes are well attested in the ENHG corpus. The list given under (39) further shows that ung-nominals derived from the verb classes in question, have been replaced by nominalized infinitives in PDG.
begehrung
vertrawung
verbleibung
wünschung
loßbrennung
a. ansehung
b. erschreckung
c. murmelung
wexelung

Ansehen
Begehren
Vertrauen
Verbleiben
Wünschen
Erschrecken
Losbrennen
Murmeln
Wechseln
'looking at'
'desiring'
'trusting'
'remaining'
'desiring'
'frightening'
$>$
$>$
$>$
$>$
'start burning'
'grumbling'
'changing'

We might conclude from the historical record that the word formation rule deriving ungnominals from verbs had a wider scope in ENHG than it has in PDG, i.e. the word formation pattern was more productive in earlier stages of German.

Assuming that $u n g$-nominalizations are closely related to their verbal bases, we expect the meaning of derived nouns to be predictable from the meaning of the corresponding verb. As a matter of fact, the meaning of ung-nominals in ENHG seems predictable to the extent that they are always able to receive an interpretation in terms of eventualitites aside from other possible interpretations. Hence, we can predict the actional properties of deverbal nouns from the meaning of the corresponding verb, as illustrated for Rüstung 'arming'.

(40) a. der lasse auch viel 1000 . Wägen Kriegs munition vnd Proviant in die Moßkaw
who have also many 1000 waggons ammunition and supplies to Moscow

\footnotetext{
${ }^{10}$ For further details concerning morphological, syntactic and semantic restrictions of the word formation pattern in PDG cf. Demske (2000) and the references quoted there.
} 
zuführen/ [...] daher die Moßkowiter auß forcht dieser Rüstung

bring $[\ldots]$ therefore the Muscovites for fear of this arming

alle offene örtter verlassen

all public places leave

'therefore, the Muscovites leave all public places for fear of this arming'

b. Dieser Tagen haben die Gül: Reuter ein Karren mit Rüstung/ [... vmbringet/

these days have the J. cavalrymen a waggon with arms surrounded

(A 299.18)

'these days the J. cavalrymen surrounded a waggon of arms'

The noun Rüstung 'arming' in (40a) has a process reading just as the verbal base does. As shown in (40b), the nominal Rüstung also appears with an instrument reading in ENHG. In PDG, Rüstung has lost the eventuality-interpretation, it is only able to refer to concrete objects. The regular meaning relationship between the derived noun and the verb holds for the majority of ung-nominalizations in ENHG. Only a few ung-nominals lack an actional interpretation altogether (cf. the examples in (16) above).

Thus, the lack of semantic restrictions on ung-nominals as well as the predictability of their meaning supports the idea that ung-nominals are nouns in a syntactic but not a semantic point of view.

\subsection{Actional properties}

While accomplishment-based nominals focus on the change of state predicate in their lexicosemantic structure in PDG, their counterparts in ENHG productively refer to either the activity predicate or the change of state predicate in their lexical semantic structure depending on the context in question. Recall that only a subclass of these nominals, namely verbs expressing locative alternation (besprïhen 'spray') and verbs denoting modification (kürzen 'shorten'), exhibit this context-dependency with respect to their interpretation in PDG.

Temporal prepositions, for one, provide an appropriate context to test the different interpretations available for ung-nominals in ENHG: in (41) the prepositions in 'while' nach 'after' trigger both readings attested for emfahung 'receiving':

(41) a. Darauff sich der König verkleid in Pilgrambß weiß/ vnd also in empfahung then himself the King disguised in pilgrim's way and so while receiving

eines Allmosens/ sich der alten Princessin zuerkennengeben/ alms' himself to the old princess revealed

'the King then disguised himself in pilgrim's way, and while receiving alms he revealed himself to the old princess'

b. vnd da der Gesand mit gutem willen/ nach empfahung der Key: Resolution and since the envoy with good will after receiving of the imp. resolution

vnd Present/ von hinnen nicht reysen wolte/ so wolle er demselben Küchen vnd and present from here not leave wanted so want he the same kitchen and

Keller zuschliessen/ [...] lassen.

cellar closed $[\ldots]$ to have

\footnotetext{
"Note that though a durative interpretation for the preposition in is rather rare in PDG (cf. in den Sommersemesterferien 'during the summer break'), it frequently occurs in ENHG.
} 
'and, because the envoy did not want to leave this place with good will, he would order to clause this envoy's kitchen and cellar'

As a complement of the preposition in 'while', empfahung gets a process reading, whereas the preposition nach 'after' triggers an event reading of its complement. Further suitable contexts for process interpretations of event nominals are provided by verbs as fortfahren 'continue' or modifiers as während 'lasting'.

$$
\begin{aligned}
& \text { dann die von Seeland nit lenger verziehen wollen/ } \\
& \text { because these of Sealand not longer wait want } \\
& \text { sondern [...] fahren fort mit außrüstung jhrer Kriegsschiff }[\ldots] \\
& \text { but continue with equipping of their war-ships }
\end{aligned}
$$

'because the people of Sealand do not want to wait any longer but continue with equipping their war-ships, $[\ldots]$ '

Accomplishment-based nominalizations thus behave as the corresponding verbal bases in comparable contexts do:
a. Während er die neu angekommenen Gäste while he the newly arrived guests
'while receiving the newly arrived guests'
empfängt, $[\ldots]$
b. Nachdem er die neu angekommenen Gäste after he the newly arrived guests
empfangen hat, $[\ldots]$
'after receiving the newly arrived guests'
receives,
Er fährt fort, seine Mannschaft mit roten Socken auszurüsten.
he continues his team with red socks to equip
'he continues to equip his team with red socks'

The historical data in (41) and (42) suggest that deriving an ung-nominal from a verbal base does not imply a shift from a lexicosemantic structure rather stressing the dynamic part to a lexicosemantic structure focussing on the change of state part as observed by Ehrich \& Rapp (2000) for PDG. Ung-nominals and the corresponding verbs behave alike as far as their actional properties are concerned.

\subsection{Ung-nominals and nominalized infinitives}

There is no doubt that nominalized infinitives are closely related to the corresponding verbal forms in PDG: (i) All verbal infinitives have a nominal counterpart, and (ii) the meaning of the nominalized infinitive is predictable from the meaning of the verbal form. ${ }^{12}$

In ENHG, ung-nominals pattern with nominalized infinitives with respect to their distribution. Both nominals appear in prepositional phrases expressing that one proposition is immediately followed by the other: ${ }^{13}$

(45) a. ist jhnen das predigen von jhrer May: wider erlaubt worden/ has them the preaching by His Majesty again allowed been

\footnotetext{
12 Though there are some instances of lexicalized nominal infinitives: Unternehmen, for example, doesn't mean 'undertaking' but 'enterprise', and Ansehen has to be translated with 'standing' not 'looking at'.

${ }^{13}$ Note that in PDG this construction is wellformed neither with ung-nominals nor with nominalized infinitives, but requires a participial phrase. The participle, however, may never occur as complement of a preposition. Die Folgen ihres Tuns realistisch einschätzend, trat sie von ihrem Amt zurück. 'realistically assessing the consequences of her actions, she stepped down'
} 
mit vermeltung/ dass sie $[\ldots]$

announcing that they

'the preaching has again been allowed to them by His Majesty, announcing that [..]'

b. jhre May. aber solches passiren zulassen nicht bedacht/ mit vermelden das [...] His Maj. however this pass to let not considered announcing that

(A 300.10)

'His Majesty, hewever, didn't consider to let this pass, announcing that $[\ldots]^{\prime}$

Moreover, both deverbal nominals may appear as conjuncts in a coordination structure, as illustrated by the data in

(46) a. in ansehen vnd betrachtung der obberürten stattlichen interceßion vnd Fürbitten

'while looking at and viewing the above mentioned intercessions and prayers'

(A 26.21)

b. sie hetten dem Bapst, Machomet, Schrifftgelehrten, Künstlern und Sophisten, they had the Pope, Machomet, scribes, artists and sophists

besser in die Woll gegriffen und ihr hülffreichs gemüht nicht nuhr

better fought and their helpful nature not alone

mit seufftzen und wünschung der Consumation erwiesen.

with sighing and wishing the consumation's proved

(FF 21.29)

'they better had proved their helpful nature not alone with sighing and wishing the consumation, but $[\ldots]^{\prime}$

with both verbs sharing their sortal interpretation.

Regarding argument selection by nominalized infinitives in ENHG, they behave as ungnominals: Underlying subjects as well as underlying objects appear as genitive complements irrespective from the sortal interpretation of the deverbal nominal. Examples for event nominals are given in

a. In Candia sitzt eine Person gefangen/ welche den Marquis de Villa
in Candia is a person captured who the Marquis de Villa

auff des GroßVeziers anstifften hat ermorden wollen.

(M 148.2)

upon the Great-Vizier's putting up has kill wanted

'somebody is captured in Candia who has wanted to kill Marquis de Villa upon putting up of the Great-Vizier'

b. Zu Wißmar soll den Reformirten das Auffbauen einer Kirchen seyn at Wismar should the reformists the building a church's has

erlaubet worden.

allowed been

'the buildung of a church is supposed to have been allowed to the members of the Reformed Church at Wismar'.

As ung-nominals share a number of properties with nominalized infinitives in ENHG, I conclude that they are as closely related to their verbal bases as nominalized infinitives are. 


\subsection{Syntactic properties of ung-nominals}

So far, ung-nominals have been considered as recategorizations of verbal stems sharing semantic properties with their derivational bases. With non-deverbal nouns ung-nominals have in common (i) that they combine with determiners (including the negative kein), (ii) that they are modified by adjectives, (iii) that they appear as complements of prepositions and (iv), that their arguments are expressed by genitive phrases. ${ }^{14}$ Examples for this noun-like behavior are displayed under

(48) a. Hingegen ist man über die WiederErlassung unserer in Seeland arrestirt however is one about the realising of our at Sealand kept hold of

gewesener Schiffe widererfreuet.

been ships again delighted

(M 30.6)

'one is, however, delighted about the release of our ships being kept hold of at Sealand'

b. da nun der Raht keine fürsehung gethan/

if now the council no provisions made

'if the council had not made any provisions now'

c. wie man sonst vernimbt/ist in der Türckey grosse Theurung/ ( $R$ 93.25) as one otherwise hears is in Turkey great increasing of prices

'there is a great increase of prices in Turkey as is otherwise heard of'

d. Was des im Hertzogthum Bremen angekommenen Frantzösischen Gesandten what the in the dukedom Bremen arrived French ambassador's

Verrichtung sey/ ist nicht zu vernehmen.

performing be is not to hear

'it is not heard of what the French ambassador's performing might be in the dukedom of B.'

e. was vor Zimmer- oder Bauholtz zu Wieder-Erbauung der abgebrandten what kind of timber to re-constructing of the burnt down

Stadt Londen/ soll gebrauchet werden/ city of London shall needed be

'what kind of timber would be needed to reconstruct the burnt down the city of London'

In other respects, however, ung-nominals act as verbs: First, there are some instances of ungnominals being modified not by an adjective but by an adverb such as of 'frequently':
vnd daß J. M.
auff seine offt Erinnerung
der Parteyen Sachen nicht/
and that His Majesty
upon his frequently reminding
of the party's affairs not
oder je gar langsam vnterschrieben
(A 274.5)
or really slowly signed

\footnotetext{
${ }^{14}$ The occurrence of plural forms is often adduced in the literature as a further argument for the noun-like behavior of ung-nominals. In the corpus under investigation, plural forms ung-noninals are restricted to the rather rare instances of object nominals as festungen 'fortresses' or besatzungen 'occupying forces' being not an issue in the present study.
} 
'and upon reminding him frequently of the party's affairs, His Majesty either did not or did really reluctantly sign '

While the adverb oft 'frequently' indicates the verbal character of the $u n g$-nominal, the possessive pronoun preceding the adverb simultaneously stresses the nominal character of the phrasal head. According to recent work about nominalization (cf. Fu et al. 2001 among others), the occurrence of adverbs within a deverbal noun indicates a syntactic structure where a verbal structure is embedded in the noun phrase. Moreover, grammaticality contrasts such as (50) provide evidence that the embedded verbal structure is a VP and no propositional phrase (i.e. CP or IP), at least not in Present-Day English. The examples are taken from Fu et al. (2001).

(50) a. His removal of the evidence deliberately resulted in obscuring the case.

b. *His removal of the evidence presumably promised a lengthy trial.

Whether an analysis along these lines carries over to deverbal ung-nouns in ENHG is at least questionable: As noted earlier, there is strong evidence for the assumption of a nominal structure. Furthermore, there are too few instances of adverbs occuring within nominals to argue on good grounds for the presence of a VP in a nominal structure. By far more interesting, also in number, are examples with the negative marker nicht 'not' attested in the corpus:

(51) a. Gedachte Fürsten haben wider des Keysers Comissarij

aforementioned princes have against the emperor's plenipotentiaries

zu Disteldorff angeschlagenes Patent ein anders anhefften lassen/ sich at Düsseldorf's recruitment poster another put up let themselves

der nicht erscheinung entschüldigt/ vnd seyn beyde Fürsten gen Cleve gezogen/ the not appearing's excused and have both princes to Kleeve moved

'aforementioned princes have $[\ldots]$ apologized for their non-appearance'

b. Die gemeine Gerüchte lauffen annoch also/ daß man in Engeland über the common rumours are still going around/ that one in England about

die nicht Annehmung des vorgeschlagenen Haages übel zu frieden sey. the non-passing of the proposed $\mathrm{H}$. badly content be

(M 176.21)

'there is said to be dissatisfaction in England about the proposed H.'s not passing'

c. weilen die Unterthanen in nicht Verkauffung ihrer Weine und anderer Wahren because the subjects in not selling their wines and other goods'

sehr traurig seyn/ daher auch die grossen Banqueroten entstehen. (M 227.9) very sad are therefore also the great bankruptcies arise

'because the subjects are very sad about not selling their wines and other goods'

Examples as in (51) are of particular interest, because the negative marker nicht 'not' is commonly assumed to indicate that the co-occurring ung-nominals do not represent nominalizations of eventualities but of propositions (cf. Zucchi 1989, Ehrich 1991 among others).

(52) a. Lotta bedauert ihre Bewerbung.

'Lotta regrets her application'

b. Lotta bedauert, dass sie sich beworben hat.

'Lotta regrets that she has applied' 
In (52), the ung-nominal alternates with a dass- 'that' clause as complement of a factive verb, indicating the propositional nature of the deverbal noun. With examples like (51) the question arises whether we have to assume a propositional phrase within the noun phrase structure (capturing the appearance of adverbs as well). Restrictions of space prevent me from going into this topic in more detail, but provide more support for the verbal character of ungnominals in ENHG.

Further support that ung-nominals are verb-like also in syntactic terms is provided by the frequent lack of either determiners and/or modifying adjectives in nominal phrases with a deverbal head. Many of these ung-nominals appear as complements of prepositions, as
a. Auff 3 di 3
ist zu Genova ein so erschrecklich Wetter/mit Wind/
on the $3^{\text {rd }}$ of this month has at Genoa a so frightening storm with wind

Donner/ Plitz vnnd Regen gewest/ welches vmb dieselbe gegend thunder lightning and rain been that in this region

$\begin{array}{llll}\text { mit einreissung } & \text { der Bäum vnd Heuser } & \text { grossen schaden } & \text { gethan/ ( } \mathrm{R} \text { 164.23) } \\ \text { with pulling down } & \text { of the trees and of houses big damage } & \text { caused }\end{array}$

'a very frightening storm with wind, thunder, lightning and rain has raged the $3^{\text {rd }}$

of this month in Genoa, causing a big damage by pulling down trees and houses

b. Das er [...] den Grafen von Lowenstein vnd Werthein an empfahung seiner that he the Count of Löwenstein and Wertheim from receiving his
behenden Lehen/ vnd anderer Rechten mercklich gehindert.
both fieves and other rights noticably prevented
'that he noticably prevented the Count of Löwenstein and Wertheim from receiving his both fieves and other rights'

(A 208.30)

The prepositional phrases in (53) display different functions: whereas the PP in (53a) functions as a modifier, the PP in (53b) expresses the verbal complement of hindern 'prevent'. Both phrases, however, are headed by an ung-nominal denoting a proposition. Note that we have to use either a participial or an infinitival clause to translate the ENHG examples into PDG. ${ }^{15}$ Since the $u n g$-nominals denote propositions it comes as no surprise that we observe something like a control effect in both instances. The implicit subject argument of the complex event nominals is interpreted with respect to a noun phrase in the matrix clause: In (53a), it is the subject ein so erschrecklich wetter 'a so frightening storm' that controls the underlying subject of einreissung 'pulling down'; in (53b), it is the object den Grafen von Lowenstein vnd Werthein 'the Count of Löwenstein and Wertheim' that controls the underlying subject of empfahung 'receiving'. Data like (53) therefore further corroborate the assumption that the agent argument is part of the noun's argument structure (though it remains implicit).

Ung-nominals show a heterogeneous syntactic behavior in ENHG. Though they have the grammatical structure of a noun phrase, they act as a verb in some respects allowing for adverbial modifiers and the negative marker nicht 'not'. It is a matter of further study whether deverbal nouns include a propositional phrase in their otherwise nominal structure.

\footnotetext{
${ }^{15}$ Ung-nominals behave in that respect as the English ing-forms, with participial clauses used as adjuncts and verbal gerunds as complements. The respective arguments of these ing-forms, however, are lexicalized as verbal objects:
}

(i) While climbing the mountain, we decided that we would go only part of the way up. (Portner 1994)

(ii) I just couldn't believe her singing this song so sweetly! (slightly modified from Parsons 1994:133) 


\section{$5 \quad$ Summing up the changes}

The historical record suggests a number of changes affecting the derivation of ung-nominals between the $18^{\text {th }}$ century and today's German:

- While the linking properties of event nominals in PDG crucially differ from the linking of their verbal counterparts, no such differences are observed with respect to the linking properties of verbs and event nominals in ENHG.

- In contrast to PDG, there is a regular meaning relation between deverbal nouns and their verbal counterparts in ENHG. Hence, no semantic restrictions govern the derivation of ung-nominals in earlier periods of German.

- Nominals based on accomplishment-verbs exhibit process readings productively in ENHG, depending on the context. Process readings of ung-nominals are rather marked in PDG as noted by Ehrich \& Rapp (2000); this observation holds for both ung-nominals derived from accomplishment-verbs as well as for ung-nominals derived from activityverbs.

- As compared to the historical record, we observe a clear difference between ung-nominals and nominalized infinitives in PDG: the coordination of both nominalization patterns yields ill-formed results as opposed to earlier periods of German where structures as the following are frequently attested:

$$
\begin{array}{lll}
\text { das Stadische Kriegsvolck hat vergangen wochen } & \text { diser orten dem Land } \\
\text { the estates' soldiery has last week } & \text { here the country }
\end{array}
$$

vnd wandersleuten mit plündern vnd Brandschatzung grossen schaden gethan and wayfarers with raiding and pillaging a lot of damage caused

'last week, the estates' soldiery has caused a lot of damage to the country and some wayfarers by raiding and pillaging'

Translating the ENHG coordination structure into PDG, we have to use the nominalized infinitive in both conjuncts, hence mit Plündern und Brandschatzen 'with raiding and pillaging' instead of the ill-formed mit Plündern und Brandschatzung. The ill-formedness suggests that ung-nominals and nominalized infinitives no longer have a common distribution in PDG with the ung-nominal developing a more noun-like semantics. ${ }^{16}$

- With respect to their syntactic properties, ung-nominals allow for adverbial modifiers as well as the negative marker nicht 'not' in ENHG. Likewise, many instances of the deverbal noun lack determiners and/or adjectival modifiers. This particularly holds for ungnominals acting as complements of prepositions. Though some relicts of this use can still be found, it is no longer a productive pattern. Typically, they are confined to particular registers.

Sie fasst ihren Entschluss unter Berücksichtigung aller Fakten.

'she is making her decision upon taking into account all facts'

\footnotetext{
16 As a matter of fact, many contexts allow for the nominalized infinitive but not the corresponding ung-nominal in PDG:

(i) Lotta kommt ins Erzählen/*in die Erzählung.

'Lotta starts telling'

(ii) $\operatorname{Im~Laufen} / *^{*}$ in der Laufung bindet Elsa ihre Schuhe zu.

'Going, Elsa laces up her shoes'

The data in (i) and (ii) differ with respect to the temporal interpretation they trigger: While the context in (i) marks the beginning of a process, (ii) expresses the simultaneity of two processes, one of which is realized by a deverbal noun. Obviously, ung-nominals are excluded in both type of contexts. For a detailled discussion of the different distribution of ung-nominals and nominalized infinitives, cf. Ehrich (1991).
} 
I consider the historical changes we observe in the history of ung-nominals since the $18^{\text {th }}$ century to be best captured in terms of a change affecting the lexical semantic structure of ung-nominals, i.e. a change shifting the focus from the first part of a complex predicate to its second part, that is, from the activity to the change of state or state part, respectively. Thus, we are able to account for the changes concerning the linking properties of event nominals as well as of nominals derived from stimulus-subject verbs. We can furthermore explain why the derivation of ung-nominals is governed by semantic restrictions in PDG, and why process readings are rather marked with ung-nominals based on verbs denoting either activities or accomplishments in PDG. To express processes in actual German with a deverbal noun, we use the nominalized infinitive or, taking into account propositional uses, participial or infinitival clauses. The gradual nominalization process of the word formation pattern - in the literal sense of nominalization - also shows with respect to its syntactic properties: as long as ungnominals share important semantic properties with corresponding verbs, they may still act verb-like in syntactic respects. Whether we have to account for these syntactic properties by assuming a propositional phrase within the nominal structure in ENHG, is pending further study. $^{17}$

Relating changes with respect to argument linking to a change in the lexicosemantic structure of ung-nominals raises the question why we observe such a nominalization process with ung-nominals but not with nominalized infinitives in the history of German, in particular in view of the fact that no such nominalization process is attested with ing-nouns in the history of English. We rather use ing-formations to translate the ENHG data into Present-Day English. ${ }^{18}$ What nominalized infinitives in German and ing-nominals in English have in common is their simultaneous use in nominal as well as verbal environments. While the verbal use of the infinitive is straightforward, it is only since the $14^{\text {th }}$ century when phonological changes motivated the replacement of the inflectional suffix -ende/-inde by -inge in building the form of the present participle (cf. Wik 1973, Nehls 1988 among others) that the verbal use of ingformations has been established. It is obviously due to this change that ing-nominals are prevented from a gradual shift in terms of nominalization throughout the history of English.

\footnotetext{
${ }^{17}$ I do not see how an approach in terms of thematic roles, as proposed for example by Barker \& Dowty (1993), would account for the diachronic properties of ung-nominals. To capture the behavior of nouns with respect to argument selection, Barker \& Dowty suggest to distinguish between verbal and nominal proto-roles. While proto-roles as Proto-Agent and Proto-Patient govern verbal argument selection, proto-roles as Proto-Part and Proto-Whole predict the linking properties of nouns:

(i) Elsa vernichtet die Unterlagen.

'Elsa destroys the documents'

(ii) ein Kapitel dieses Buches

'a chapter of this book'

The argument Elsa is syntactically expressed as subject-NP in (i), because this argument satisfies properties ascribed to the Proto-Agent such as causing an event and bringing about a change of state. The object-denoted participant Unterlagen 'documents' on the other hand entails a crucial property of a Proto-Patient, i.e. it is undergoing a change of state. Kapitel 'chapter' and Buch 'book' in (ii) figure as Proto-Part and Proto-Whole. To account for argument selection properties of deverbal nouns, Barker \& Dowty assume that the distribution of nominal and verbal proto-roles is independent from the ontological type of predicates: just as deverbal nouns entail verbal proto-roles, stative verbal predicates (cf. contain, surround) may entail nominal proto-roles.

Evaluating this approach only with respect to the historical record of deverbal ung-nouns, I see no way to capture the changes with respect to argument structure by means of a framework using thematic roles. Since the changes neither affect the verbal or nominal status of particular roles (the proto-roles linked to deverbal nouns continue to be verbal throughout history) nor the inventory of proto-roles, the historical facts favor accounts of argument selection in terms of lexical decomposition over accounts using thematic roles.

${ }^{18}$ Both German ung-nominalizations and English ing-nominalizations evolve from a common source. Old English productively uses both forms of the derivational affix, cf. freming 'Vollbringung', bodung 'Predigen' (the distribution depending on the verbal inflection class, cf. Quirk/Wrenn 1955), while the use of -ing in Old High German is restricted to the Ripuarian dialect area with ung-nominals abounding otherwise (s. Wilmanns 1896:374).
} 


\section{Conclusion}

My examination of ung-nouns in ENHG has revealed the different nature of the word formation pattern in earlier periods of German where the derivation of ung-nominals means a mere syntactic recategorization of verbal bases. At that period in the history of German, the derivational process has no effects whatsoever on the lexicosemantic structure of the verbs in question. Hence, no differences between deverbal nouns and their verbal counterparts arise with respect to argument linking.

\section{Sources}

[A] = Der Aviso des Jahres 1609. Ed. by W. Schöne. Faksimiledruck. Leipzig: Harrassowitz 1939.

$[\mathrm{AC}]=$ Annus Christi 1597. Historische erzöhlung/der fürnembsten Geschichten vnd handlungen/so in diesem 1597. Jahr (...) abgelauffen (...). Rorschach 1597. Nachdruck: Walluf-Nedeln: Sändig 1977.

$[\mathrm{CF}]=$ Confessio Fraternitatis 1615. In: Johann Valentin Andreae. Ed. by R. v. Dülmen. Stuttgart: Calwer Verlag 1973, 31-42 (= Quellen und Forschungen zur Württembergischen Kirchengeschichte, Bd. 6).

$[\mathrm{CH}]=$ Chymische Hochzeit: Christiani Rosenkreutz. 1616. In: Johann Valentin Andreae. Ed. by R. v. Dülmen. Stuttgart: Calwer Verlag 1973, 43-124 (= Quellen und Forschungen zur Württembergischen Kirchengeschichte, Bd. 6).

$[\mathrm{FF}]$ = Fama Fraternitatis 1614. In: Johann Valentin Andreae. Ed. by R. v. Dülmen. Stuttgart: Calwer Verlag 1973, 15-30 (= Quellen und Forschungen zur Württembergischen Kirchengeschichte, Bd. 6).

$[M]=$ Mercurius 1667. Nordischer Mercurius. Welcher kürtzlich vorstellet/ was in diesem 1667. Jahre an Novellen aus Europa einkommen ist. Hamburg 1667.

$[R]=$ Die Relation des Jahres 1609. Ed. by W. Schöne. Faksimiledruck. Leipzig: Harrassowitz 1940.

$[\mathrm{WR}]=$ Wickram, Georg. Das Rollwagenbüchlin. Text nach der Ausgabe von Johannes Bolte. Stuttgart: Reclam [Druck Straßburg 1555].

\section{References}

Barker, Chris / David Dowty (1993): Non-Verbal Thematic Proto-Roles. The Proceedings of NELS 23, GLSA: Amherst/MA., 49-62.

Bartsch, Renate (1985): On Aspectual Properties of Dutch and German Nominalizations. In: Vicenzo Lo Cascio / Co Vet (eds.): Temporal Structure in Sentence and Discourse. Dordrecht: Foris, 7-39.

Bierwisch, Manfred (1983): Semantische und konzeptuelle Repräsentation lexikalischer Einheiten. In: Rudolf Rủžička / Wolfgang Motsch (eds.): Untersuchungen zur Semantik. Berlin: Akademie-Verlag, 61-100.

Bierwisch, Manfred (1996): Lexical Information from a Minimalist Point of View. In: Chris Wilder / HansMartin Gärtner / Manfred Bierwisch (eds.): The Role of Economy Principles in Linguistic Theory. Berlin: Akademie-Verlag, 227-266.

Demske, Ulrike (1999): Nominalisierungen im Deutschen und Englischen: Überlegungen zu einer Theorie sprachlichen Wandels. In: Siegfried Kanngießer / Petra Vogel (eds.): Elemente des Sprachwandels. Opladen: Westdeutscher Verlag, 98-138.

Demske, Ulrike (2000): Zur Geschichte der Ung-Nominalisierung im Deutschen. Ein Wandel morphologischer Produktivität. Beiträge zur Geschichte der deutschen Sprache und Literatur 122, 365-411.

Ehrich (Ullmer-), Veronika (1977): Zur Syntax und Semantik von Substantivierungen im Deutschen. Kronberg/Taunus: Scriptor.

Ehrich, Veronika (1991): Nominalisierungen. In: Arnim von Stechow / Dieter Wunderlich (eds.): Semantics. An International Handbook of Contemporary Research. Berlin: de Gruyter, 441-458.

Ehrich, Veronika / Irene Rapp (2000): Sortale Bedeutung und Argumentstruktur: -ung-Nominalisierungen im Deutschen. Zeitschrift für Sprachwissenschaft 19, 244-302.

Eisenberg, Peter (1998): Grundriss der deutschen Grammatik. Bd. 1: Das Wort. Stuttgart: Metzler.

Esau, Helmut. (1973): Nominalization and Complementation in Modern German. Amsterdam: North Holland.

Fu, Jingqi / Thomas Roeper / Hagit Borer (2001): The VP within Process Nominals: Evidence from Adverbs and the VP Anaphor $D o-S o$. Natural Language and Linguistic Theory 19, 549-582.

Gloning, Thomas (1991): Fremdwörter in der Relation von 1667. Unpublished Manuscript. University of Tübingen.

Grimshaw, Jane (1990): Argument Structure. Cambridge/Mass.: MIT Press.

Jackendoff, Ray (1990): Semantic Structures. Cambridge/Mass.: MIT Press. 
NehIs, Dietrich (1988): On the Development of the Grammatical Category of Verbal Aspect in English. In: Josef Klegraf / Dietrich Nehls (eds.): Essays on the English Language and Applied Linguistics on the Occasion of G. Nickel's 60th Birthday. Heidelberg: Groos, 173-198.

Oh, Y.-O. (1985): Wortsyntax und Semantik der Nominalisierungen im Gegenwartsdeutsch. Konstanz: Gorre.

Parsons, Terence (1994): Events in the Semantics of English: A Study in Subatomic Semantics. Cambridge/Mass.: MIT Press.

Portner, Paul (1994): A Uniform Semantics for Aspectual -ing. The Proceedings of NELS 24, GLSA: Amherst/MA., 507-517.

Rapp, Irene (2001a): Linkingsteuerung im Verbalbereich: Welche Bedeutungsaspekte sind relevant? Linguistische Arbeitsberichte 76, 185-219.

Rapp, Irene (2001b): Argumentstruktur und Erstgliedinterpretation bei deverbalen Derivaten - ein semantikbasierter Ansatz. To appear in: Folia Linguistica.

Quirk, Randolph / Charles L. Wrenn (1955): An Old English Grammar. London: Routledge.

Wechsler, Stephen (1995): The Semantic Basis of Argument Structure. Stanford/CA.: CLSI Publications.

Wellmann, Hans (1975): Deutsche Wortbildung: Typen und Tendenzen in der Gegenwartssprache, Hauptteil 2: Das Substantiv. Düsseldorf: Schwann (= Sprache der Gegenwart 32).

Wik, Berit (1973): English Nominalizations in -ing. Synchronic and Diachronic Aspects. Doctoral Dissertation University of Uppsala.

Wilmanns, Wilhelm (1896): Deutsche Grammatik. Gotisch, Alt-, Mittel- und Neuhochdeutsch. II. Abteilung: Wortbildung. Strassburg: Trübner.

Wunderlich, Dieter (1997): CAUSE and the Structure of Verbs. Linguistic Inquiry 28, 27-68.

Zucchi, Alessandro (1989): The Language of Propositions and Events: Issues in the Syntax and the Semantics of Nominalizations. Doctoral Dissertation, University of Amherst/MA. 